\title{
Study of Nitrogen Release Pattern in Different Oil Coated Urea Fertilizers in Light Textured Soils
}

\author{
S.M. Shilpha ${ }^{1 *}$, T.M. Soumya ${ }^{1}$, L.S. Pradeep ${ }^{1}$ and L. Rajashekhar ${ }^{2}$ \\ ${ }^{1}$ Department of Agronomy, ${ }^{2}$ Department of Soil Science, College of Agriculture, University of \\ Agricultural and Horticultural Sciences, Navile, Shivamogga, Karnataka, India \\ *Corresponding author
}

\section{A B S T R A C T}

\begin{tabular}{|l|}
\hline K e y w o r d s \\
Maize, Nitrogen, \\
Neem coated urea, \\
Pongamia oil coated \\
urea, Castor oil coated \\
urea, Release pattern, \\
Incubation.
\end{tabular}

\section{Introduction}

Nitrogen $(\mathrm{N})$ is a vital element found in all living things. Crops require nitrogen in relatively large amounts making it the nutrient most often deficient in crop production. Despite nitrogen being one of the most abundant elements on in the universe, nitrogen deficiency is probably the most common nutritional problem affecting plants worldwide. Healthy plants contain 3-4 per cent nitrogen in their aboveground tissues. It is a major component of chlorophyll, amino acids and building blocks of proteins. Nitrogen is a component of energy-transfer compounds, such as ATP (adenosine triphosphate) which allows cells to conserve and use the energy released in metabolism. Soil nitrogen can be divided into three categories viz., (i) small inorganic components consisting of ammonical, nitrate and nitrite nitrogen (ii) large organic components consisting of the residues of plant and other organics and (iii) elemental nitrogen component in the soil atmosphere. Plants absorb nitrogen in the form of nitrate and ammonium ions. Soil nitrogen changes rapidly from one form to another compared to any other mineral nutrients (Mahorana et al., 2015). The concentration of any such product at any given point of time depends on various factors such as soil type, climate, organic 
matter content, soil microbial population, moisture, aeration and inorganic inputs like fertilizers. The inorganic soil nitrogen component is usually small and easily depleted and hence cannot support plant growth for a long time.

However release of organically bound nitrogen from urea fertilizers by coating with slow soluble materials like natural oils, tar, mud etc by the process of mineralization makes sure the unabated supply of nitrogen in simple forms. Therefore, evaluation of nitrogen release pattern is essential to have a rational basis for developing sound nitrogen management practice

Urea can be taken up by plant roots and leaves. Once entered inside the plant, it is converted to ammonium and assimilated as amino acids and amides.

The form of $\mathrm{N}$ uptake is mainly determined by its abundance and accessibility, which make $\mathrm{NO}_{3}{ }^{-}$and $\mathrm{NH}_{4}{ }^{+}$the most important $\mathrm{N}$ forms for plant nutrition under agricultural conditions (Vyas et al., 1991). With minor importance, the form of $\mathrm{N}$ uptake is also subject to plant preferences, by which plants maintain their cation/anion balance during uptake. However, some species seem to have an obligatory preference which even prevents their growth on certain other $\mathrm{N}$ sources.

In general, uptake of a certain $\mathrm{N}$ form closely matches the growth-related demand of the plant, at least when $\mathrm{N}$ transport to the root surface is not limiting. In addition, many plants accumulate large pools of $\mathrm{N}$ during vegetative growths which are remobilized in the generative stage. As a consequence, systems responsible for $\mathrm{N}$ transport need to be tightly regulated in their expression and activity upon sensing $\mathrm{N}$ availability and plant demand (Duann et al., 2009).

\section{Materials and Methods}

A incubation study was conducted to study the nitrogen release pattern of different coated urea fertilizers such as neem coated urea, pongamia oil coated urea and castor oil coated urea The sandy clay loam soil of the experimental area was filled in polyethylene bags, each having an average weight of $15 \mathrm{~kg}$ and analysed for initial NPK status. It was kept for 15 days for settlement with frequent watering. The oil coated urea such as neem coated $\left(\mathrm{T}_{1}\right)$, Pongamia oil $\left(\mathrm{T}_{2}\right)$ and Castor oil coated urea $\left(\mathrm{T}_{3}\right)$ were placed at $10 \mathrm{~cm}$ below the surface and watered twice a week in order to maintain field capacity. These three oil coated urea fertilizers were replicated seven times and kept in green house conditions. The bags were marked at 20 and $40 \mathrm{~cm}$ below the placements of fertilizers. The soil samples were drawn at 0-20 and 20-40 $\mathrm{cm}$ depth at 15 day's intervals up to 75 DAI.

Collected soil samples were analysed for its available NPK status by using standard methods as follows. Available nitrogen is estimated by alkaline potassium permanganate method and determined by using Kjeldahl's distillation method (Jackson, 1973), available phosphorus was estimated by brays method and determined by spectrophotometer (Jackson, 1973) and available potassium was estimated by flame photometry by using Neutral normal ammonium acetate as extractant. The experiment was carried out in a complete Randomized design and analysed statistically as per procedure suggested by Gomez and Gomez (1978).

\section{Results and Discussion}

Yield maximization of any crop demands on the process associated with uptake of nutrients, translocation, partitioning, assimilation and mobilization of nutrients at 
different growth stages of crop. These multitude processes is influenced by genetic potential of the variety, cultural practices, soil manipulation and climatic factor.

In the present study, the results of satellite experiment on available NPK status of experimental soil as influenced by incorporation of different slow release nitrogenous fertilizers at various depths indicate the following trends (Tables 1, 2 and $3)$.

\section{Available nitrogen $\left(\mathrm{Kg} \mathrm{ha}^{-1}\right)$}

\section{At 0-20 cm depth}

Available nitrogen status did not differ significantly due to application of slow release nitrogenous fertilizers at 15 DAI (Days after incubation). At 30 DAI, at a depth of $0-20 \mathrm{~cm}$, the higher available nitrogen status was observed in treatment which received COCU (329.63 $\mathrm{kg} \mathrm{ha}^{-1}$ ). Whereas in treatment which received POCU was recorded higher available nitrogen (291.17 $\left.\mathrm{kg} \mathrm{ha}^{-1}\right)$ compared to treatment which received NCU $\left(280.84 \mathrm{~kg} \mathrm{ha}^{-1}\right) .45$ and 60 DAI, soil nitrogen status differed significantly. However, significantly higher available nitrogen was recorded in treatment which received NCU (392.48 and $412.48 \mathrm{~kg} \mathrm{ha}^{-1}$ ) followed by POCU (384.70 and $399.70 \mathrm{~kg} \mathrm{ha}^{-1}$ ). While, lower available nitrogen was recorded in treatment which received COCU (369.43 and $381.43 \mathrm{~kg} \mathrm{ha}^{-1}$ ).

At 75 and 90 DAI, nitrogen differed significantly due to incorporation of different slow release nitrogenous fertilizers. The higher available nitrogen was recorded in the treatment which received NCU (402.48 and $342.62 \mathrm{~kg} \mathrm{ha}^{-1}$ ) followed by treatment which received POCU (386.70 and $323.42 \mathrm{~kg} \mathrm{ha}^{-1}$ ). While lower available nitrogen was registered in treatment which received COCU (367.43 and $302.43 \mathrm{~kg} \mathrm{ha}^{-1}$ ).

\section{At 20-40 cm depth}

At a depth 20-40 cm also, available nitrogen status did not differ significantly due to application of slow release nitrogenous fertilizers at 15 DAI and 30 DAI.

At 45 DAI and 60 DAI, nitrogen status in soil was varied significantly among the treatments. The higher nitrogen was recorded in $\mathrm{T}_{3}$ i.e. COCU (279.29 and $292.15 \mathrm{~kg} \mathrm{ha}^{-1}$ ) followed by treatment which received POCU (270.37 and $279.79 \mathrm{~kg} \mathrm{ha}^{-1}$ ). However, lower available nitrogen was registered in treatment which received NCU (267.89 and $277.03 \mathrm{~kg}$ $\mathrm{ha}^{-1}$ ).

At 75 DAI and 90 DAI, available nitrogen status was differed significantly. The higher nitrogen was recorded in treatment which received COCU (283.58 and $273.43 \mathrm{~kg} \mathrm{ha}^{-1}$ ) and it was seconded by treatment which received POCU (270.65 and $260.37 \mathrm{~kg} \mathrm{ha}^{-1}$ ). However, lower nitrogen status was recorded with treatment which received NCU (266.17 and $257.60 \mathrm{~kg} \mathrm{ha}^{-1}$ ).

It is observed from the data that the release pattern of nitrogen studied varied due to applied treatments T1 (Neem coated urea), T2 (Pongamia oil coated urea), T3 (Castor oil coated urea). From all the sources, it is evident that initially there was a slow buildup of nutrients studied. Nitrogen steadily increased in its status till 60 days after incorporation of slow release nitrogenous fertilizers, then started showing decreased trend.

This ensures continuous and optimal supply of nitrogen to match the requirements of crops at different stages of growth and increased nitrogen efficiency in soil. Neem coated urea helps in gradual increase in $\mathrm{NO}_{2}{ }^{+} \mathrm{NO}_{3}-\mathrm{N}$ levels in soil up to a period of one month, where as a sharp increase in $\mathrm{NO}_{2}{ }^{+} \mathrm{NO}_{3}-\mathrm{N}$ 
levels within a period of 7-15 days was observed in the soil treated with uncoated urea (Vyas et al., 1991).

Neem coated urea releases ammonical form of nitrogen by hydrolysis process and provide available form which in turn increase availability of nitrogen in soil. Depth wise observations clearly indicated that there are little leaching losses of nitrogen observed in neem coated urea compared to the treatments which received pongamia and castor oil coated urea due to regulation and retardation of nitrification process with steady release of nutrients.

The results are in conformity with findings of Nhamo et al., (1997), Ashara Pengnoo et al., (2001), Gurcan et al., (2007), Vimlesh and Giri (2009) and Mubarak et al., (2010) and controversy with results of Virendra Singh (2013) and Thimmaiah (2015).

\section{Available Phosphorus (Kg ha $\left.{ }^{-1}\right)$}

\section{At 0-20 cm depth}

Available phosphorus status did not differ significantly due to application of slow release nitrogenous fertilizers at 15 DAI. At 30 DAI, Soil phosphorus status did not differed significantly.

The higher phosphorus was recorded in treatment which received NCU $(82.90 \mathrm{~kg}$ ha $\left.{ }^{1}\right)$ followed by treatment which received POCU $\left(82.08 \mathrm{~kg} \mathrm{ha}{ }^{-1}\right)$. Whereas, lower available phosphorus was recorded in treatment which received COCU $(79.29 \mathrm{~kg}$ $\mathrm{ha}^{-1}$ ).

At 45 and 60 DAI, phosphorus status was varied significantly among the treatments. The higher phosphorus was recorded in treatment which received NCU (105.56 and $111.98 \mathrm{~kg} \mathrm{ha}^{-1}$ ) followed by treatments which received POCU (103.35 and $109.35 \mathrm{~kg} \mathrm{ha}^{-1}$ ). However, lower phosphorus was registered in treatment which received COCU (96.75 and $102.75 \mathrm{~kg} \mathrm{ha}^{-1}$ ).

At 75 and 90 DAI, available phosphorus status was differed significantly. The higher available phosphorus was recorded in treatment which received NCU (101.84 and $81.84 \mathrm{~kg} \mathrm{ha}^{-1}$ ) and it was seconded by treatment with incorporation of POCU (99.35 and $79.35 \mathrm{~kg} \mathrm{ha}^{-1}$ ).

However, lower phosphorus status was recorded with treatment which received COCU (92.75 and 72.75 kg ha ${ }^{-1}$ ). Phosphorous maintained its steady increment till end of the study.

\section{At 20-40 cm depth}

At a depth 20-40 cm also, available phosphorus status did not differ significantly due to application of slow release nitrogenous fertilizers at 15 DAI and 30 DAI,

At 45 DAI and 60 DAI, phosphorus status in soil was varied significantly among the treatments.

The higher phosphorus was recorded in $\mathrm{T}_{1}$ i.e. NCU (80.56 and $88.27 \mathrm{~kg} \mathrm{ha}^{-1}$ ) followed by treatment which received POCU (78.35 and $86.35 \mathrm{~kg} \mathrm{ha}^{-1}$ ). However, lower available phosphorus was registered in treatment which received COCU (71.75 and $79.32 \mathrm{~kg} \mathrm{ha}^{-1}$ ). At 75 DAI and 90 DAI, available phosphorus status was differed significantly.

The higher phosphorus was recorded in treatment which received NCU (78.70 and $67.70 \mathrm{~kg} \mathrm{ha}^{-1}$ ) and it was seconded by treatment which received POCU (76.35 and $65.92 \mathrm{~kg} \mathrm{ha}^{-1}$ ). However, lower phosphorus status was recorded with treatment which received COCU (69.89 and $59.75 \mathrm{~kg} \mathrm{ha}^{-1}$ ). 
Table.1 Available nitrogen status $\left(\mathrm{kg} \mathrm{ha}^{-1}\right)$ in soil at different intervals and depths in incubation study for release pattern of nitrogen as influenced by incorporation of different slow release nitrogenous fertilizers

\begin{tabular}{|c|c|c|c|c|c|c|c|c|c|c|c|c|}
\hline \multirow{3}{*}{ Treatment } & \multicolumn{2}{|l|}{15 DAI } & \multicolumn{2}{|c|}{30 DAI } & \multicolumn{2}{|c|}{45 DAI } & \multicolumn{2}{|l|}{60 DAI } & \multicolumn{2}{|l|}{75 DAI } & \multicolumn{2}{|l|}{90 DAI } \\
\hline & \multicolumn{12}{|c|}{ Depth (cm) } \\
\hline & 0-20 & $20-40$ & $0-20$ & $20-40$ & $0-20$ & $20-40$ & $0-20$ & $20-40$ & $0-20$ & $20-40$ & $0-20$ & $20-40$ \\
\hline $\mathbf{T}_{1}$ & 259.39 & 247.60 & 280.84 & 258.46 & 392.48 & 267.89 & 412.48 & 277.03 & 402.48 & 266.17 & 342.62 & 257.60 \\
\hline $\mathbf{T}_{2}$ & 263.91 & 253.79 & 291.17 & 263.79 & 384.70 & 270.37 & 399.70 & 279.79 & 386.70 & 270.65 & 323.42 & 260.37 \\
\hline $\mathbf{T}_{3}$ & 268.81 & 257.29 & 329.63 & 265.43 & 369.43 & 279.29 & 381.43 & 292.15 & 367.43 & 283.58 & 302.43 & 273.43 \\
\hline S. Em \pm & 6.58 & 4.03 & 3.55 & 4.30 & 6.80 & 4.06 & 7.98 & 4.18 & 4.15 & 5.09 & 4.19 & 5.01 \\
\hline $\mathrm{CD}$ at $5 \%$ & NS & NS & 10.53 & NS & 20.21 & 12.07 & 23.72 & 12.41 & 12.34 & 15.13 & 12.46 & 14.90 \\
\hline
\end{tabular}

Table.2 Available phosphorus status $\left(\mathrm{kg} \mathrm{ha}^{-1}\right)$ in soil at different intervals and depths in incubation study for release pattern of nitrogen as influenced by incorporation of different slow release nitrogenous fertilizers

\begin{tabular}{|c|c|c|c|c|c|c|c|c|c|c|c|c|}
\hline \multirow{3}{*}{ Treatment } & \multicolumn{2}{|c|}{15 DAI } & \multicolumn{2}{|c|}{30 DAI } & \multicolumn{2}{|l|}{45 DAI } & \multicolumn{2}{|l|}{60 DAI } & \multicolumn{2}{|c|}{75 DAI } & \multicolumn{2}{|c|}{90 DAI } \\
\hline & \multicolumn{12}{|c|}{ Depth (cm) } \\
\hline & 0-20 & $20-40$ & 0-20 & $20-40$ & $0-20$ & $20-40$ & 0-20 & $20-40$ & $0-20$ & $20-40$ & $0-20$ & $20-40$ \\
\hline $\mathbf{T}_{1}$ & 72.90 & 57.90 & 82.90 & 72.90 & 105.56 & 80.56 & 111.98 & 88.27 & 101.84 & 78.70 & 81.84 & 67.70 \\
\hline $\mathbf{T}_{2}$ & 72.37 & 57.37 & 82.08 & 72.37 & 103.35 & 78.35 & 109.35 & 86.35 & 99.35 & 76.35 & 79.35 & 65.92 \\
\hline $\mathbf{T}_{3}$ & 69.58 & 54.58 & 79.29 & 69.58 & 96.75 & 71.75 & 102.75 & 79.32 & 92.75 & 69.89 & 72.75 & 59.75 \\
\hline S. Em \pm & 1.55 & 1.55 & 1.63 & 1.55 & 1.24 & 1.24 & 1.08 & 1.29 & 1.34 & 1.26 & 1.12 & 1.36 \\
\hline $\mathrm{CD}$ at $5 \%$ & NS & NS & NS & NS & 3.67 & 3.67 & 3.21 & 3.84 & 4.00 & 3.74 & 3.33 & 4.03 \\
\hline
\end{tabular}

DAI: Days after incubation $\mathrm{T}_{1}$ : Neem coated urea $\mathrm{T}_{2}$ : Pongamia oil coated urea $\mathrm{T}_{3}$ : Castor oil coated urea NS: Non- significant 
Table.3 Available potassium status $\left(\mathrm{kg} \mathrm{ha}^{-1}\right)$ in soil at different intervals and depths in incubation study for release pattern of nitrogen as influenced by incorporation of different slow release nitrogenous fertilizers

\begin{tabular}{|c|c|c|c|c|c|c|c|c|c|c|c|c|}
\hline \multirow{3}{*}{ Treatment } & \multicolumn{2}{|l|}{15 DAI } & \multicolumn{2}{|l|}{30 DAI } & \multicolumn{2}{|l|}{45 DAI } & \multicolumn{2}{|l|}{60 DAI } & \multicolumn{2}{|l|}{75 DAI } & \multicolumn{2}{|c|}{90 DAI } \\
\hline & \multicolumn{12}{|c|}{ Depth $(\mathrm{cm})$} \\
\hline & 0-20 & $20-40$ & 0-20 & $20-40$ & 0-20 & $20-40$ & $0-20$ & $20-40$ & 0-20 & $20-40$ & 0-20 & $20-40$ \\
\hline $\mathbf{T}_{1}$ & 315.96 & 275.96 & 362.80 & 315.96 & 422.54 & 335.96 & 453.40 & 354.53 & 361.50 & 336.39 & 305.00 & 311.67 \\
\hline $\mathbf{T}_{2}$ & 267.06 & 227.06 & 323.97 & 266.34 & 377.77 & 287.06 & 407.77 & 308.49 & 372.86 & 286.91 & 297.33 & 262.77 \\
\hline $\mathbf{T}_{3}$ & 234.77 & 194.77 & 294.76 & 233.34 & 339.27 & 251.62 & 369.27 & 273.62 & 359.73 & 252.91 & 296.07 & 230.48 \\
\hline S. Em \pm & 4.55 & 4.55 & 4.80 & 4.95 & 5.04 & 3.86 & 5.13 & 5.46 & 1.37 & 5.97 & 1.56 & 5.91 \\
\hline $\mathrm{CD}$ at $5 \%$ & NS & NS & NS & NS & 14.98 & 11.45 & 15.24 & 16.22 & 4.06 & 17.72 & 4.64 & 17.56 \\
\hline
\end{tabular}

DAI: Days after incubation $\mathrm{T}_{1:}$ Neem coated urea $\mathrm{T}_{2}$ : Pongamia oil coated urea $\mathrm{T}_{3}$ : Castor oil coated urea

Fig.1 Release pattern of nitrogen in soil at different intervals and depths in incubation study as influenced by incorporation of different slow release nitrogenous fertilizers
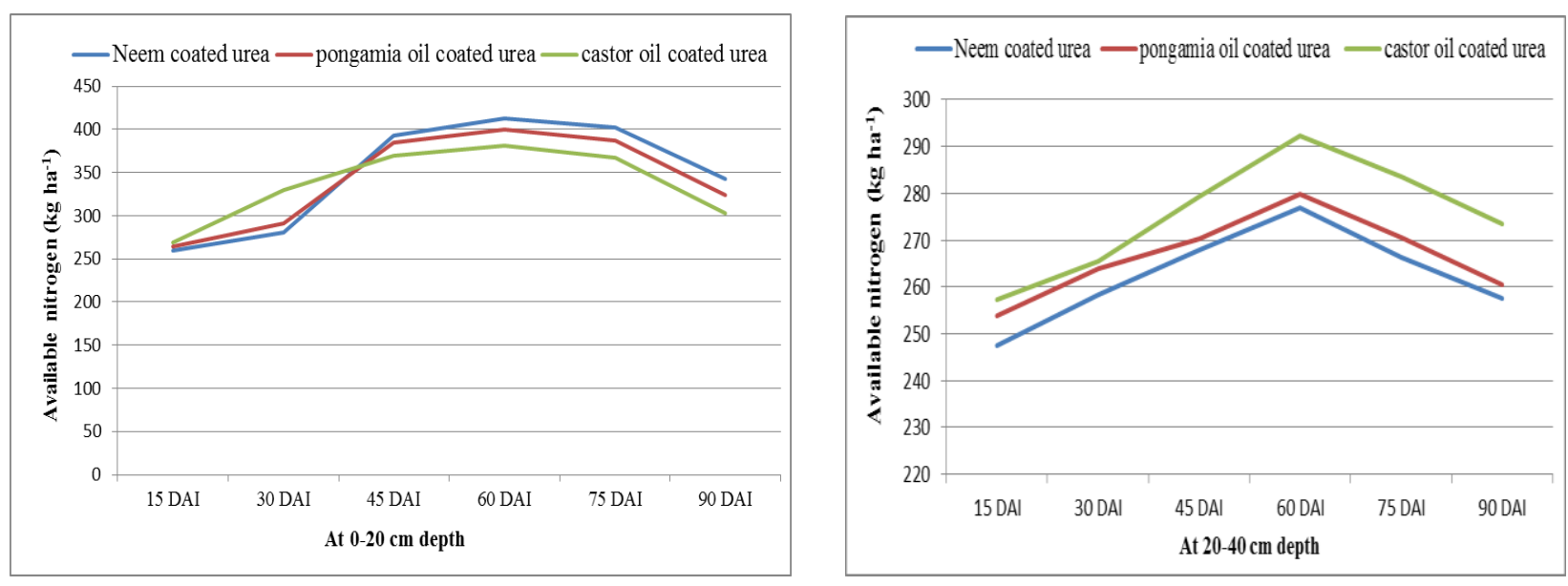
Available potassium $\left(\mathrm{Kg} \mathrm{ha}^{-1}\right)$

\section{At 0-20 cm depth}

Available potassium status did not differ significantly due to application of slow release nitrogenous fertilizers at 15 and 30 DAI.

At 45 and 60 DAI, potassium status was varied significantly among the treatments. The higher potassium was recorded in treatment with incorporation of NCU $(422.54$ and $453.40 \mathrm{~kg} \mathrm{ha}^{-1}$ ) followed by POCU (377.77 and $407.77 \mathrm{~kg} \mathrm{ha}^{-1}$ ). However, lower potassium was registered in treatment with application of COCU (339.27 and $369.27 \mathrm{~kg}$ $\left.\mathrm{ha}^{-1}\right)$. At 75 and $90 \mathrm{DAI}$, available potassium status of soil was differed significantly. The higher available potassium was recorded in treatment with incorporation of $\mathrm{NCU}(361.50$ and $305.0 \mathrm{~kg} \mathrm{ha}^{-1}$ ) and it was seconded by treatment with application of POCU (372.86 and $297.33 \mathrm{~kg} \mathrm{ha}^{-1}$ ). However, lower potassium status was recorded with treatment with application of COCU (359.73 and $296.07 \mathrm{~kg} \mathrm{ha}^{-1}$ ).

\section{At 20-40 cm depth}

At a depth $20-40 \mathrm{~cm}$, available potassium status did not differ significantly due to application of slow release nitrogenous fertilizers at 15 DAI and 30 DAI.

At 45 DAI and 60 DAI, potassium status in soil was varied significantly among the treatments. The higher potassium status was recorded in T1 i.e. NCU (335.96 and 354.53 $\mathrm{kg} \mathrm{ha}^{-1}$ ) followed by treatment which received POCU (287.06 and $308.49 \mathrm{~kg} \mathrm{ha}^{-1}$ ). However, lower available potassium was registered in treatment which received COCU (251.62 and $\left.273.62 \mathrm{~kg} \mathrm{ha}^{-1}\right)$. At $75 \mathrm{DAI}$ and $90 \mathrm{DAI}$, available potassium status was differed significantly. The higher available potassium was recorded in treatment which received NCU (286.91 and $262.77 \mathrm{~kg} \mathrm{ha}^{-1}$ ). However, lower potassium status was recorded with treatment which received COCU (252.91 and $\left.230.48 \mathrm{~kg} \mathrm{ha}^{-1}\right)$. Potassium followed the similarity to that of nitrogen (Fig. 1). Again, in respect of different sources, neem coated urea showed little higher values than other in test due to its higher nitrification inhibition efficiency. On the other hand, castor oil coated recorded relatively lower values for all nutrients. Pongamia oil coated urea at all stages of observation showed little higher values to that of castor oil coated urea, however for potassium it is higher.

In the present study, results clearly indicate that with regard to release pattern of nitrogen, slow and steady release of nitrogen was observed in the treatment which received neem coated urea where as little faster release of nitrogen in soil was observed with respect to the treatment which received pongamia oil coated urea and castor oil coated urea. This might due to their difference in regulation efficiency of nitrification and mineralization process. In general with increase in incubation period the release of $\mathrm{N}$ significantly increased from 30 days after incubation up to 60 days then after it decreased probably due to loss of nitrogen by volatilization. In this study moisture status was maintained at field capacity so that inorganic fertilizers easily dissolved and released the nutrient. Early mineralization of inorganic component was the main reason behind releasing nitrogen form. For 60, 75 and 90 days after incubation also, higher value of available nitrogen was obtained by the treatment which received neem coated urea.

\section{References}

Ashara Pengnoo, Wanna, L., Nisakorn, K. and Mana, K.M., 2002, Nitrogen mineralization in soil amended with 
mesocarp fiber of oil palm and other wastes: A green study. J. Sci. Tech., 24(1): 1-8.

Duann L.L., Zhang, M., Liu, G., Shang Z.C. and Yang, Y., 2009, Nutrient release characteristics and use efficiency of slow- and controlled release fertilizers. National centre for biological sciences, 20(5): 1118-24.

Gomez, K.A. and Gomez, A.A., 1984, Statistical Procedures for Agricultural Research, Second Edition, John Wiley and Sons, New York, p. 680.

Gurcan, G, Serap Kirmizi and Hulya Arslan, 2007, Nitrogen Mineralization in the soils of alpine mat community: An incubation experiment under laboratory condition. Turk J Bot., 31: 277-286.

Jackson, M.L., 1973, Soil Chemical Analysis (Ed.). Prentice Hall of India (Pvt.) Ltd., New Delhi.

Moharana, P.C., Biswas, D.R. and Datta, S.C., 2015, Mineralization of Nitrogen, Phosphorus and Sulphur in Soil as Influenced by Rock Phosphate Enriched Compost and Chemical Fertilizers. J. Indian Society of Soil Sci., 63(3): 283-293.

Mubarak, A.R., Gali, A.M., Mohamed, A.G., Steffens, D. and Awadel Karim, 2010,
Nitrogen mineralization from five manures as influenced by chemical composition and soil type. Comm. Soils Sci. Plant Anal., 41: 1903-1920.

Nhamo, N., Murwira, H.K. and Giller, K.E., 1997, The relationship between nitrogen mineralization patterns and quality indices of cattle manures from different smallholder farms in Zimbabwe. Soil Productivity Research Laboratory (SPRL), Private Bag 3757, Marondera, Zimbabwe.

Thimmaiah, M., 2015, Effect of integrated nutrient management on growth and yield of rainfed ragi (Eleusine coracana L. gaertn.). M.Sc. (Agri.) Thesis, UAHS, Shimoga.

Virendra Singh, 2013, Effect of different organic manures and fertilizers on yield and nutrient uptake of maize. $M$. Sc. (Agri.) Thesis, UAS, Bangalore.

Vimlesh, K. and Giri, A.K., 2009, Nitrogen mineralization in soil amended with crop residue: An incubation experiment under flooding condition. e- J. Chem., 8(1): 25-28. Vyas, B.N., Godrej and Mistry, K.B., 1991, Development and evaluation of neem extract as a coating for urea fertilizer. Fert. News, 8: 19-25.

\section{How to cite this article:}

Shilpha, S.M., T.M. Soumya, L.S. Pradeep and Rajashekhar, L. 2017. Study of Nitrogen Release Pattern in Different Oil Coated Urea Fertilizers in Light Textured Soils. Int.J.Curr.Microbiol.App.Sci. 6(11): 1282-1289. doi: https://doi.org/10.20546/ijcmas.2017.611.153 